\title{
Studies on the Chloroplasts of Desmids. II.
}

\author{
BY \\ N. CARTER, M.Sc. \\ With Plates XIX and XX and one Figure in the Text. \\ Contents.
}

IX. The Chloroplasts of Micrasterias.

T $\mathrm{N}$ this genus the general form of the chloroplast in some species has 1 long been recognized. Thus an extensive chloroplast plate containing numbers of scattered pyrenoids was figured by Ralfs (1848) in several species, and later Delponte (1873) and W. and G. S. West (1904-11) also indicated the presence of ridges on the surface of the chloroplast in some other species.

But although it has long been observed that in those species of the genus having very flattened cells the chloroplasts are correspondingly flattened and plate-like, in the case of those species in which the cells are comparatively thicker very little is known concerning the chloroplasts.

The species whose chloroplasts have been examined during this investigation are $M$. conferta, Lund., $M$. denticulata, Bréb., $M$. Thomasiana, Arch., $M$. rotata, (Grev.) Ralfs, $M$. papillifera, Bréb., $M$. radiata, Hass., M. Crux-Melitensis, (Ehrenb.) Hass., M. pinnatifida, (Kütz.) Ralfs, $M$. apiculata, (Ehrenb.) Menegh., M. Americana, (Ehrenb.) Ralfs, M.oscitans, Ralfs, var. mucronata, (Dixon) Wille, and $M$. truncata, (Corda) Bréb. In spite of the fact that the chloroplasts of these species present very diverse appearances when examined in the front view, it has been found that they are all built up on the same plan. On comparing, for instance, the chloroplasts of a species having very flattened cells, e.g. M. denticulata, with those of a species whose cells are in proportion very much thicker, e.g. M. truncata, considerable differences are at once apparent ; cf. Pl. XIX and XX, Figs. 2 and 25 ; nevertheless both can be considered as variations of one simple type.

There is in every case one chloroplast in each semi-cell, and this consists primarily of an extensive flattened plate, having approximately the same outline as the cell-wall, and occupying a central position, its surfaces parallel to the front faces of the semi-cell. As a rule from both sides of this axile plate various ridges are given off, stretching towards the cell-wall. The size, number, and disposition of these ridges vary considerably according to the species, and even to some extent amongst individuals of the same

[Annals of Botany, Vol. XXXIII No. CXXXI. July, rgrg.] 
species, according to the physiological condition of the cell. This is particularly the case with some of the flat-celled species, where frequently in some individuals no trace of ridges is to be found at all, whereas in others they are quite distinct. In other thicker celled species, e.g. $M$. truncata, they are often so large, numerous, and profusely branched, that the axile plate is frequently quite hidden by them. The size and prominence of the ridges depends largely on the thickness of the cell, because they stretch out towards the cell-wall, chiefly at right angles to the axile plate.

In the flat-celled species of Micrasterias the axile plate does not usually occupy more than one-third the entire space between the two front walls of the semi-cell (Figs. $3-8$ and Io), but the thickness of the chloroplast always varies considerably according to the amount of stroma starch contained in it. The axile plate extends into all the peripheral lobes and projections of the cell-wall, and is slightly hollowed out at the base of the semi-cell for the accommodation of the nucleus (Figs. 2, 9, and 24). In outline it may be very similar to the cell-wall, or it may be even more intricately incised and lobed. Sometimes it seems to be drawn out at intervals into threadlike strands which apparently connect up the chloroplast to the peripheral layer of cytoplasm lining the cell-wall. This happens when the chloroplast is not sufficiently massive to extend right up to the cell-wall at all points.

In those species with very thick cells the axile plate is not so evident in the front view as in the case of those species having flattened cells (Figs. I3, I9, and 25). It is seen, however, in the end view or in transverse sections as an extremely thin plate lying in the middle of the cell, halfway between the front walls (Fig. 27). Towards the sides of the cell it usually loses its identity in the profusion of branching ridges (Figs. I4, 20, 2I, and 27). Very often in such cases it has no definite plate-like form, but consists of a more or less irregularly shaped mass connecting up the huge ridges one with another, these forming by far the more important part of the chloroplast (Fig. 2I).

In nearly all the species examined a more or less extensive hollowing away of the central axile plate was noticed in the upper region of the polar lobe. This is often seen as a semicircular or more elongated space free from chloroplast in the extreme apex of the cell. In the flat-celled species this apical hollowing rarely extends for more than one-fourth the distance from apex to nucleus, and is frequently less (Figs. 2 and 24). In the thickcelled species, however, the axile plate is sometimes shortened from the apex by as much as two-thirds its greatest length, so that the chloroplast is distinctly bilobed (Figs. I5, I9, and 25). When this happens the ridges often spread round over the internal surface of the wall so that the absence of the axis in the apical region may not at first sight be noticed, but in 
other cases the colourless gap may be quite obvious. In such individuals there are often apparently two chloroplasts in each semi-cell, separated from each other by a colourless space in the median region. On careful examination, however, it is usually possible to locate the remains, at any rate, of the axile plate just beyond the nucleus connecting up the two apparently separate chloroplasts (Fig. 25). In the genus Micrasterias the formation of two separate chloroplasts in a single semi-cell by means of this extensive hollowing away in the apical region was not very frequently observed, but in Cosmarium Ralfsii, ${ }^{1}$ which has a chloroplast exactly similar to that of the thick-celled species of Micrasterias, the same phenomenon also occurs, and here all stages in the progressive shortening of the axis in the median region have been observed, including the final stage in which two distinct chloroplasts were present. It is quite possible that this also happens occasionally in those species of Micrasterias having very thick cells.

The ridges, if present, project from both surfaces of the axile plate, extending to the cell-wall. If the distance from the central axis to the cell-wall be considerable, i.e. in the thick-celled species, the ridges frequently fork and branch (Figs. 20-22 and 27); in most cases, however, they are simple and unbranched (Figs. I4 and I8). Their free edges are rarely quite straight, but either undulate (Figs. 2, 15, and 17), or, as is more often the case, they are much more elaborately ornamented (Figs. I 3 and 24). Sometimes their edges may be drawn out to form short thread-like outgrowths attached to the peripheral layer of cytoplasm lining the cellwall, as in the case of the edges of the axile plate (Fig. I9).

In many of the flat-celled species the ridges project only very slightly from the surface of the plate, and in some individuals may be scarcely perceptible. When this is the case they are usually to be found following the outlines of the more important incisions of the plate, just a little distance from its edge (Figs. 2 and 24).

Very often there are two very prominent ridges on both surfaces of the axile plate in the median region. These usually extend right from the nucleus at the base of the semi-cell up into the polar lobe, one on each side of the apical gap in the axis (Text-fig.; Figs. 9, I5, and I7). They usually stretch for a little way over the surface of the nucleus itself, which is therefore embraced by eight claw-like projections, the outgrowths of the four ridges on each chloroplast of the cell. In species having such prominent median ridges other smaller ones may or may not be present. If present they are sometimes irregularly scattered (Figs. I 3 and I5), or may be in definite positions round the more important incisions as before (Text-fig.).

1 This species was for some time believed to have chloroplasts in the form of parietal bands; its axile form was first discovered by Dr. Lïtkemiiller, who figured it and published a short note on it in his paper, Zur Kenntnis der Desmidiaceen Böhmens, I9IO. 
In those species of the genus having the thickest cells the ridges are comparatively speaking very large and profusely branched. Their arrangement is usually very irregular, and they extend in all directions towards the cell-wall (Figs. I9 and 25). Here the axial part of the chloroplast is quite insignificant, and it is not surprising that in the apical and median regions of the cell the axis is often wanting.

It is probable that this absence of chlorophyll from the apical region of so many individuals is a manifestation of the attempt on the part of the organism to fill the more peripheral parts of the semi-cell with photosynthetic material as soon as possible, at the risk of robbing the interior of its normal share, since the parts of the chloroplast underlying the cell-wall are obviously more important in the process of photosynthesis than the more internal parts. This theory is supported by observations of the behaviour of the chloroplasts during cell-division. When the young semicell is newly formed it contains at first no chlorophyll, but soon the chloroplast of the older semi-cell begins to bud, sending two lobes through the isthmus, one on each side of the nucleus into the young semi-cell. In the very flattened cells of some species this bilobed form is not retained in a very conspicuous manner as the chloroplast streams more and more into the new semi-cell, and very soon the median part between them also begins to bud, so that the ingrowing chloroplast becomes practically semicircular in outline, excepting for a small gap often found in its extreme apex. This is because all parts of the cell are equally good for photosynthesis, and it is just as important that the median part of the cell should be provided with chlorophyll as the more lateral parts. But in the thicker celled species the two small lobes first projected into the new semi-cell quickly expend their substance in an attempt to mantle the cell-wall by the formation of numerous large ridges which spread out in all directions as more and more chloroplast enters from the older semi-cell. Whilst this is happening the axis has very little chance of developing in the median part of the cell, as indeed there is little need for it to do so, since the median part of the front walls is probably already sufficiently mantled by ridges extending from the left and right lobes of the chloroplast. Thus it often happens that when the division of the chloroplast occurs at the isthmus, the chloroplast in the new semi-cell is still distinctly bilobed, or, if the growth of the tawo chloroplast lobes has been so rapid that the axis in the median part has not been able to develop at all, then these two lobes become completely isolated when separated from the original chloroplast by the division at the isthmus, and consequently the new semicell contains two distinct chloroplasts instead of one.

The pyrenoids in the chloroplasts of this genus are often extremely numerous (Figs. 2, 9, and I7), but at the same time they are very variable both in size and number. In individuals of the same species, for instance, 
there may be thirty fairly large pyrenoids, or as many as eighty to a hundred rather smaller ones.

It is in those species having compressed cells and a simple axile chloroplast plate that the pyrenoids are most numerous, and here they are scattered indiscriminately. In the thick-celled species, where the ridges of the chloroplast have become relatively more important, the pyrenoids are reduced in number, and are more or less confined to those parts of the axis which give rise to the ridges (Fig. 27), whilst in those species having branched ridges they may be found also in the more peripheral parts of the ridges at the points of branching (Figs. 2I and 22).

\section{M. conferta.}

This species has a rather simpler chloroplast than any other species examined. Only one specimen was available for examination, and this had in each semi-cell a simple axile plate of very irregular shape. Ridges were only very slightly developed; and were found only along a few, not all, of the larger incisions. The pyrenoids were eight or nine in number; they were variable in size and scattered irregularly (Fig. I).

\section{$M$. denticulata and $M$. Thomasiana.}

The chloroplasts of these two species greatly resemble each other. There is a large axile plate which is usually provided with a series of more or less distinct, though comparatively small, ridges following the outlines of the more important incisions between the lobes (Figs. 2-8). The prominence of the ridges, however, varies considerably with different individuals. This variation is again to be correlated with the amount of stroma starch present in the individual. If little starch be present, then the ridges along the incisions of the cell will usually be very distinct, whereas, if the chloroplast becomes very distended with stroma starch, the axile plate is often swollen to three or four times its former thickness and the ridges are lost.

In $M$. Thomasiana the ridges parallel to the sinus project for some distance into the two outgrowths of the cell-wall at the base of the semicell ; the third or median lobule was not strongly developed in the material examined.

In both species the pyrenoids are very numerous, there being usually about sixteen to seventy in $M$. Thomasiana, and twenty to forty in the case of $M$. denticulata (Fig. 2). . Occasionally in the latter species there may be more than a hundred pyrenoids in a single chloroplast.

\section{M. papillifera.}

In this species there is a series of very distinct ridges arranged all round the incisions of the axile plate (Fig. 24). They are fairly large, very 
sharply defined, and have their free edges produced to form outgrowths of various shapes. The two median ridges continue for some distance beyond the incisions on each side of the polar lobe, but never extend quite as far as the nucleus. The pyrenoids are large and number from twelve to fifteen.

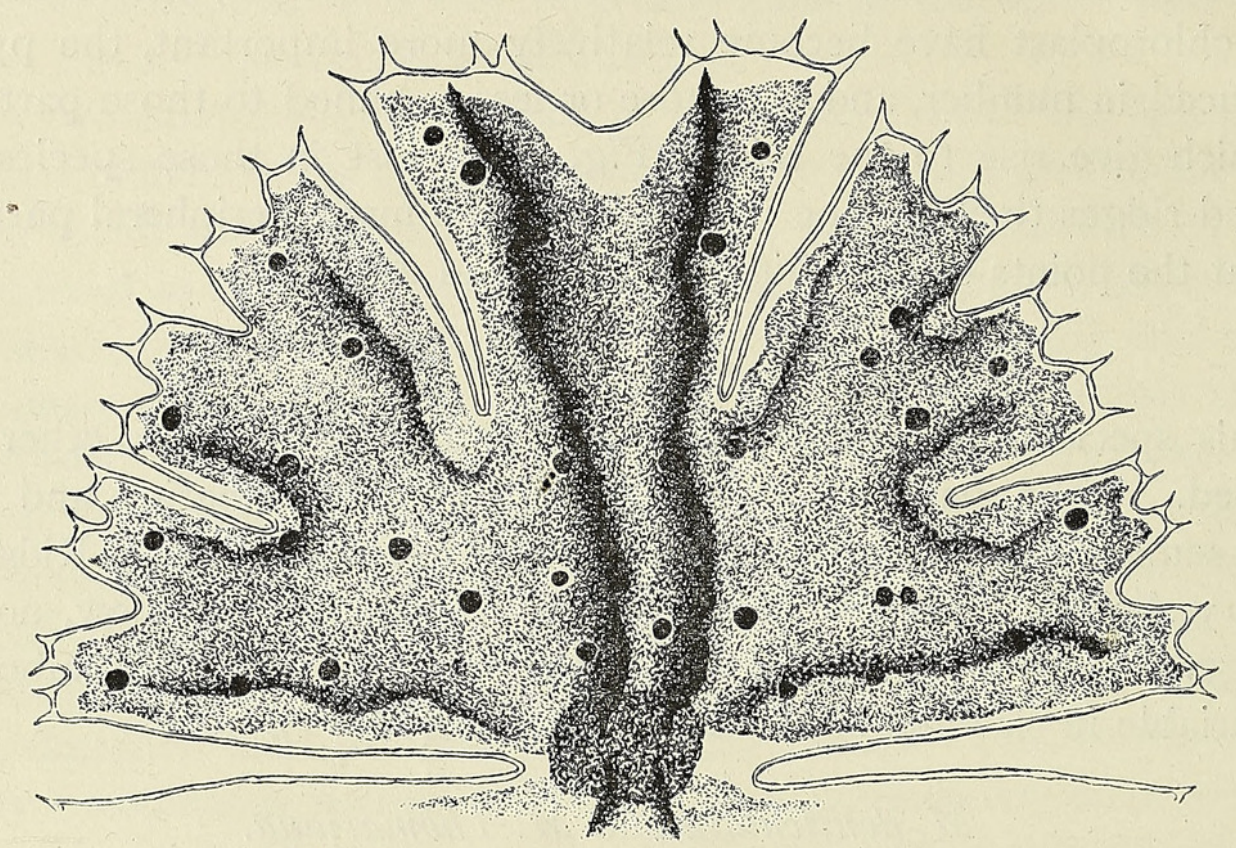

M. apiculata, (Ehrenb.) Menegh. $\times 510$.

\section{$M$. rotata and $M$. apiculata.}

The most striking feature of the chloroplasts of these two species is that there are two very prominent ridges on each side of the axis stretching right from the nucleus to the apex of the chloroplast. These are rather larger in $M$. apiculata than in $M$. rotata because of the relatively greater thickness of the cell; cf. Text-fig. with Figs. 9 and IO. In the former species there is in addition a series of ridges, almost equally striking, following the outlines of the principal incisions of the axile plate. In $M$. rotata ridges are usually wanting in the lateral lobes of the cell, and even if present they are only very slightly developed. The pyrenoids in $M$. apiculata usually number about thirty; in $M$. rotata they are often much more numerous, and may be more than eighty.

\section{$M$. radiata and $M$. Crux-Melitensis.}

The chloroplasts of these two species are quite similar to each other (Figs. I5, I7, and 23). The axile plate extends for quite a considerable distance into the peripheral outgrowths of the cell-wall, and has two rather definite median ridges projecting from both its surfaces. There are various other ridges (Fig. I 8), very irregularly arranged, perhaps more so in the case of $M$. radiata than in $M$. Crux-Melitensis. In the only specimen of the latter species examined there were about thirteen pyrenoids in each semi-cell, whilst in $M$. radiata they vary from eight to thirty. 


\section{$M$. pinnatifida,}

In this tiny species two very prominent median ridges are to be seen in the front view, and towards the lateral edges of the cell the plate thickens abruptly, at the same time splitting into two lamellae. This is best seen in the end view (Fig. I2). It was only possible to examine one individual, and this had three pyrenoids in each semi-cell, one in the polar lobe and one in each lateral lobe of the cell (Fig. II).

\section{Americana.}

This species has ridges which are very large and conspicuous, but probably unbranched. There are two very distinct median ridges visible in the front view, but these usually seem to be displaced either to one side or the other (Fig. 13). This is due to the fact that the front faces of the cell are not flat, and the cell is much thicker in the middle than at the edges (Fig. 14). Consequently the cell always tilts over to one side when resting on a flat surface. The peg-like outgrowths of the cell-wall on the polar lobe are usually the cause of this tilting to one side of the cell, but in the variety examined these were not strongly developed.

Besides the median ridges of the chloroplast there are various others radiating from the region of the nucleus towards the periphery. In spite of the thickness of the cell, the central axis, as in all the other species dealt with so far, retains its definite plate-like form. In Fig. I4 the axis is seen to be very distended with stroma starch, which has not yet, however, spread as far as the ridges. The pyrenoids number about twelve to fifteen and are scattered throughout the axis of the chloroplast.

\section{$M$. oscitans, var. mucronata, and M. truncata.}

These two species have relatively thicker cells than any of the others which were examined. In both the ridges are variable in number, but they are always large and very much branched, quite superseding the central axis in their much greater development (Figs. 2I and 27). The delicacy of the branching of the chloroplast is largely dependent on the amount of stroma starch present in it. The formation of much starch causes the chloroplast to become very distended, and thus the elegance of the stroma starch-free chloroplast is lost ; cf. Figs. 20 and 21.

The shortening of the axile plate in the median region of the cell is frequently considerable, and the chloroplast is in consequence often distinctly bilobed (Figs. I9 and 25). In such cases a transverse section near the top of the semi-cell is quite different from one near the nucleus. The former naturally cuts through the two separate lobes of the chloroplast, and two distinct masses are to be seen (Fig. 22), whilst towards the base of the semi-cell a continuous central axis is seen with various plates or branched 
ridges stretching towards the cell-wall in all directions (Fig. $2 \mathrm{I}$ ). In the front view two median ridges are usually quite conspicuous in comparison with the others, and that part of the central axis lying between them, even where it is present, is often very delicate and only found after careful focusing (Fig. 25). Occasionally specimens of $M$. truncata have been observed in which two distinct chloroplasts were present in each semi-cell, the axis in the median region of the cell being altogether absent, but as a rule the remains of the axile plate can be seen just above the nucleus.

When there is a very extensive hollowing away of the axis in the upper part of the semi-cell, the ridges in the apical region often spread themselves closely over the inner surface of the cell-wall, forming a more or less definite parietal layer (Figs. 25 and 26 ).

The pyrenoids in both species vary very much in size, and usually number about five to ten in each semi-cell, although there may be as many as twenty. They are usually to be found embedded in the thicker parts of the chloroplast, where the ridges arise from the central axis, or even in the more peripheral parts of the ridges themselves. Occasionally pyrenoids occur in the parietal part of the chloroplast in the apical lobe where the axis in this region is wanting (Fig. 26), but the majority of the pyrenoids are always to be found in the interior of the cell. They are very often seen to be in a state of active division, two or more small ones being constricted off from a single large one.

\section{Summary of the Special Characters of MiCrasterias.}

In all the species examined there is normally one chloroplast in each semi-cell, and all the different forms encountered can be considered as variations of one simple type.

There is always a more or less distinct axile plate parallel to the front faces of the semi-cell in the central position, and from this there usually arise numbers of ridges or plates which project towards the cell-wall in various directions. The relative size of the axis and ridges varies with different species.

The prominence of the ridges seems to depend on the thickness of the cell ; in the more flattened cells of some species they are insignificant and may under certain physiological conditions be altogether absent, but in the thicker celled species they are very large and may sometimes even be branched. The ridges in the latter case constitute by far the more important part of the chloroplast, the axis often becoming very thin and indefinite in form.

With the increase in size and importance of the ridges, the pyrenoids become more restricted in number and disposition, occurring only in the more massive parts of the chloroplast. 


\section{Carter.-Studies on the Chloroplasts of Desmids. II. 303}

In most species a tendency was noticed for the axis of the chloroplast to become shortened in the apical lobe of the cell. This is more pronounced in the thicker celled species, in which the chloroplast may even tend to become parietal in this region by reason of the absence of the axis. Sometimes the shortening of the axis in the median region extends through the whole length of the semi-cell, in which case two chloroplasts are present instead of one.

In conclusion, I wish to express my gratitude to the Birmingham Natural History and Philosophical Society and also to the Royal Society for grants to help in the cost of reproducing the plates illustrating this work. My thanks are also due to Professor G. S. West for much valuable help and advice throughout the investigation.

THE Botanical LABORATORY, UNIVERSITY OF BIRMINGHAM.

\section{BIBLIOGRAPHY.}

Delponte, J. B. (1873): Specimen Desmidiacearum subalpinum, Augustae Taurinorum. Memor.

d. R. Accad. d. Scienze di Torino, Ser. 2, vol. xxviii, 1873 .

LüTKemüller, J. (1910) : Zur Kenntnis der Desmidiaceen Böhmens. Verhandl. der k. k. zool.-bot. Gesell., lx, 19 Iо.

Ralfs, J. (1848): The British Desmidiaceae. London, 1848 .

West, W. and G. S. (1904-11): Monograph of the British Desmidiaceae. Ray Society, vol. i, 1904 ; vol. ii, 1905 ; vol. iii,.1908; vol. iv, I9II.

\section{DESCRIPTION OF PLATES XIX AND XX.}

Illustrating Miss N. Carter's paper on Chloroplasts of Desmids. II.

During the prolonged processes of preparation the specific characters of Desmids often become obliterated, but all the species were identified, either in the living or carefully fixed condition, by Professor G. S. West.

PLATE XIX. (All $\times 5$ IO).

Fig. I. Micrasterias conferta, Lund.

Figs. 2-8. $M$. denticulata, Bréb. Fig. 2, front view; Fig. 3, longitudinal median section; Figs. 4-8, transverse sections taken at intervals from the sinus to the apex of the semi-cell, showing the large axile plate, and the comparatively small ridges cut in various directions.

Figs. 9 and 10. M. rotata, (Grev.) Ralfs. Fig. 9, front view of semi-cell ; Fig. Io, slightly oblique transverse section, showing the median ridges cut transversely. section.

Figs. I I and I2. M. pinnatifida, (Kütz.) Ralfs. Fig. I I, front view; Fig. I2, optical transverse

PLATE XX. (All $\left.\times 5^{10}\right)$.

Figs. I3 and I4. M. Americana, (Ehrenb.) Ralfs, var. Lewisiana, West. Fig. I3, front view ; Fig. I4, optical transverse section, showing the axis of the chloroplast greatly distended with starch. 


\section{Carter.-Studies on the Chloroplasts of Desmids. II.}

Figs. I5-18. M. radiata, Hass. Fig. I5, front view of semi-cell showing the bilobed form of the chloroplast owing to the shortening of the axis in the median region; Fig. I7, front view of another individual which does not show this phenomenon; Fig. I6, longitudinal oblique section, the ridges cut irregularly in surface section; Fig. 18, transverse section.

Figs. 19-22. M. oscitans, Ralfs, var. mucronata, (Dixon) Wille. Fig. I9, front view of individual having a distinctly bilobed chloroplast in each semi-cell ; Fig. 20, transverse section showing the whole chloroplast distended with stroma starch ; Fig. 2I, transverse section of an individual whose chloroplast contains little starch excepting in the immediate neighbourhood of the pyrenoids; Fig. 22, transverse section of a specimen whose chloroplast is deeply cleft owing to the shortening of the axis in the median region.

Fig. 23. M. Crux-Melitensis, (Ehrenb.) Hass., front view.

Fig. 24. M. papillifera, Bréb., front view.

Figs. 25-27. M. truncata, (Corda) Bréb. Fig. 25, front view of an individual, the axis of whose chloroplast is much shortened and very delicate in the median region; Fig. 26, surface view of the polar lobe of the same individual seen from the end, showing how the cell-wall is mantled with parietal films of chloroplast when the axis is wanting in this region of the cell ; Fig. 27 , optical transverse section of the basal part of the semi-cell. 


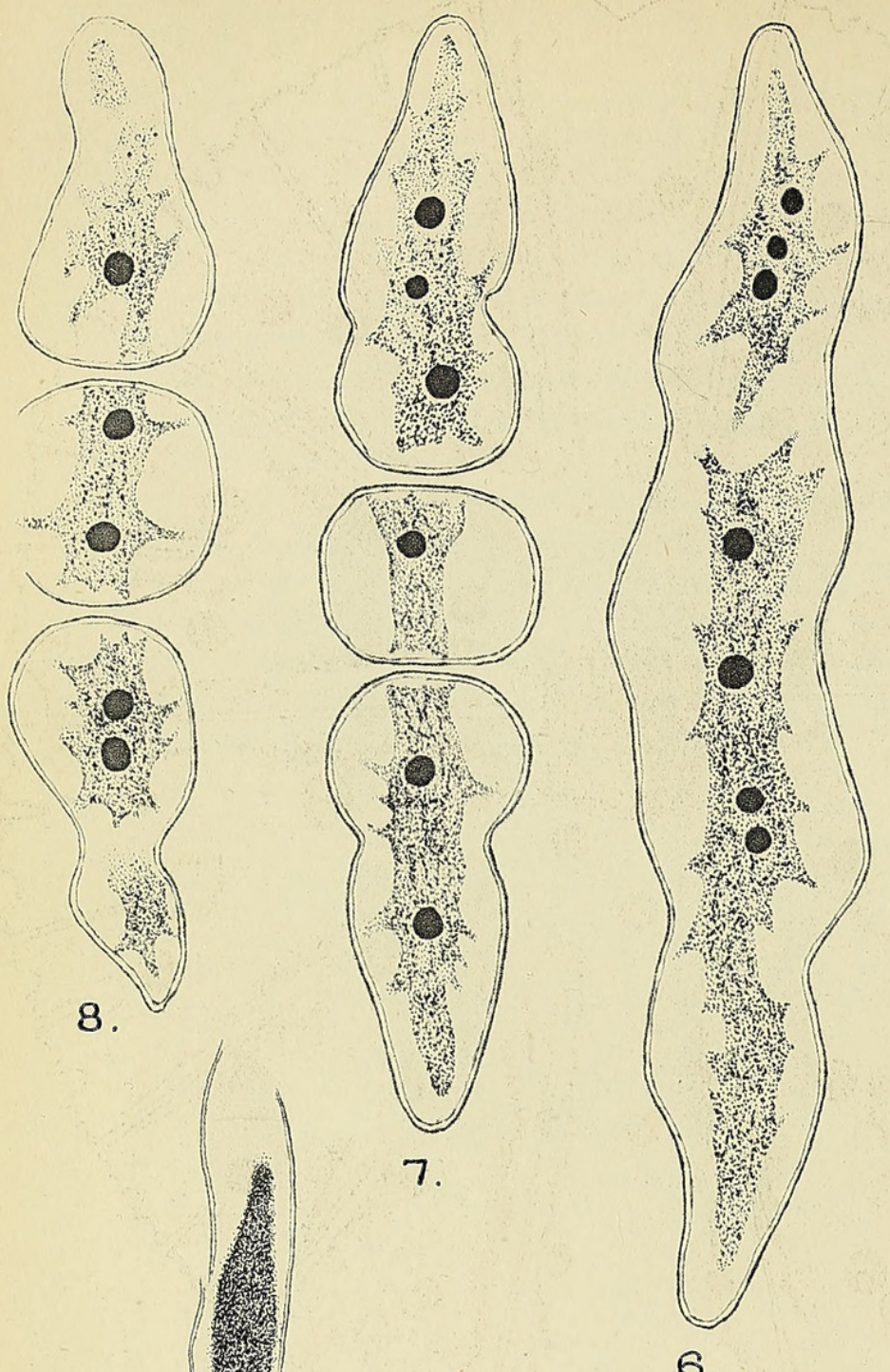

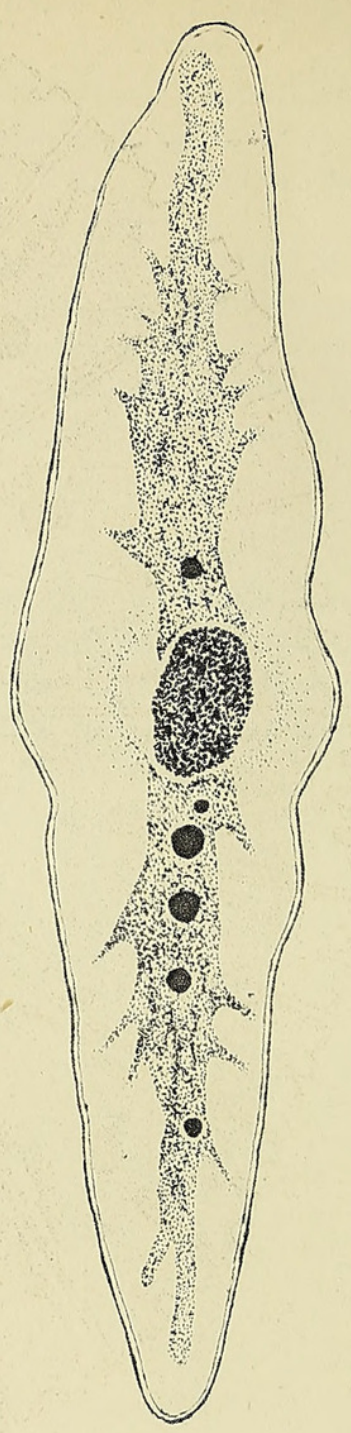

5

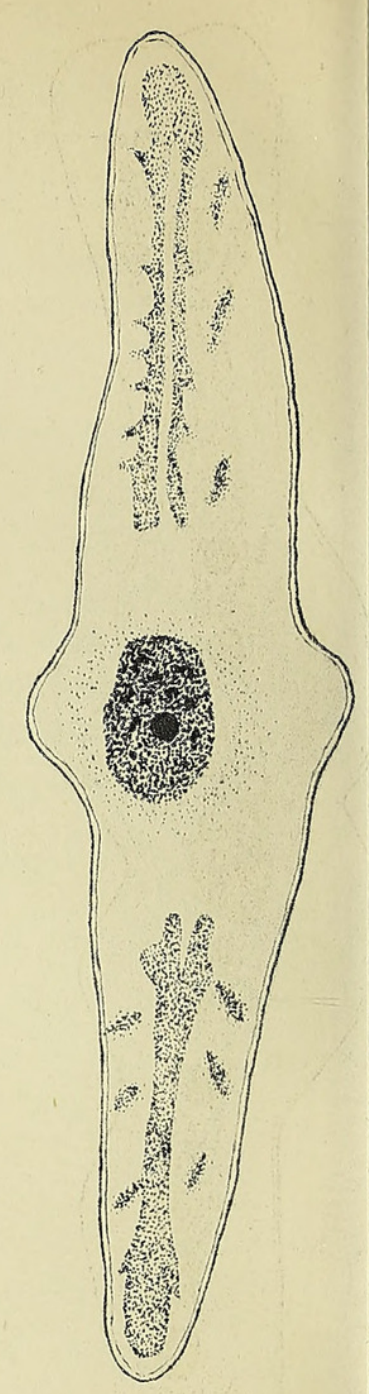

4.

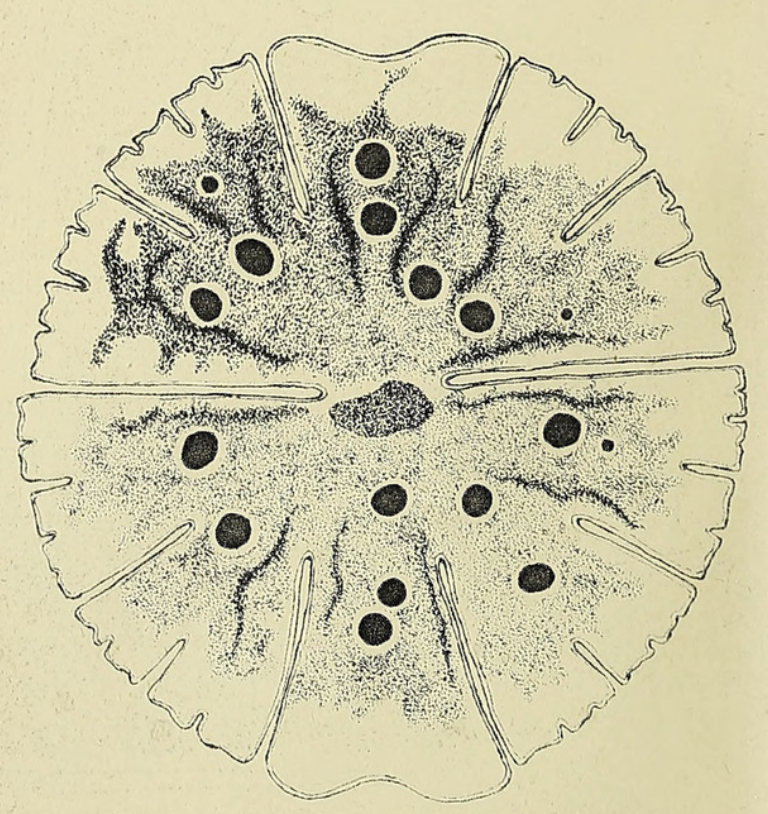

1.

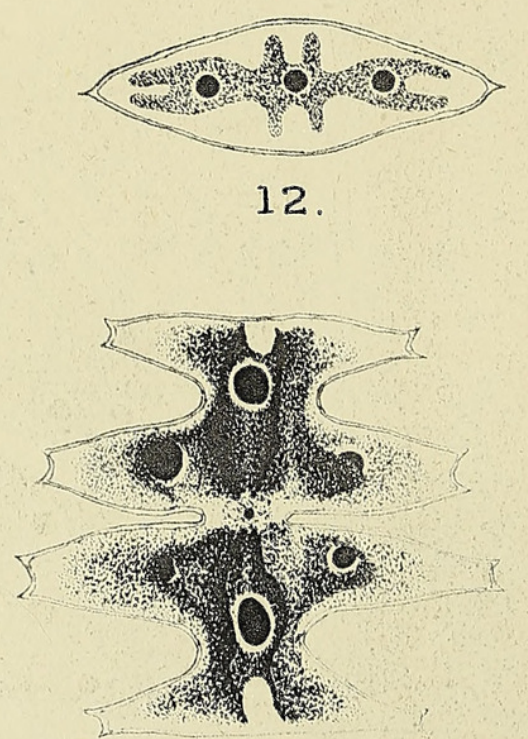

11. 
Vol.XXXIII, Pl. XIX.
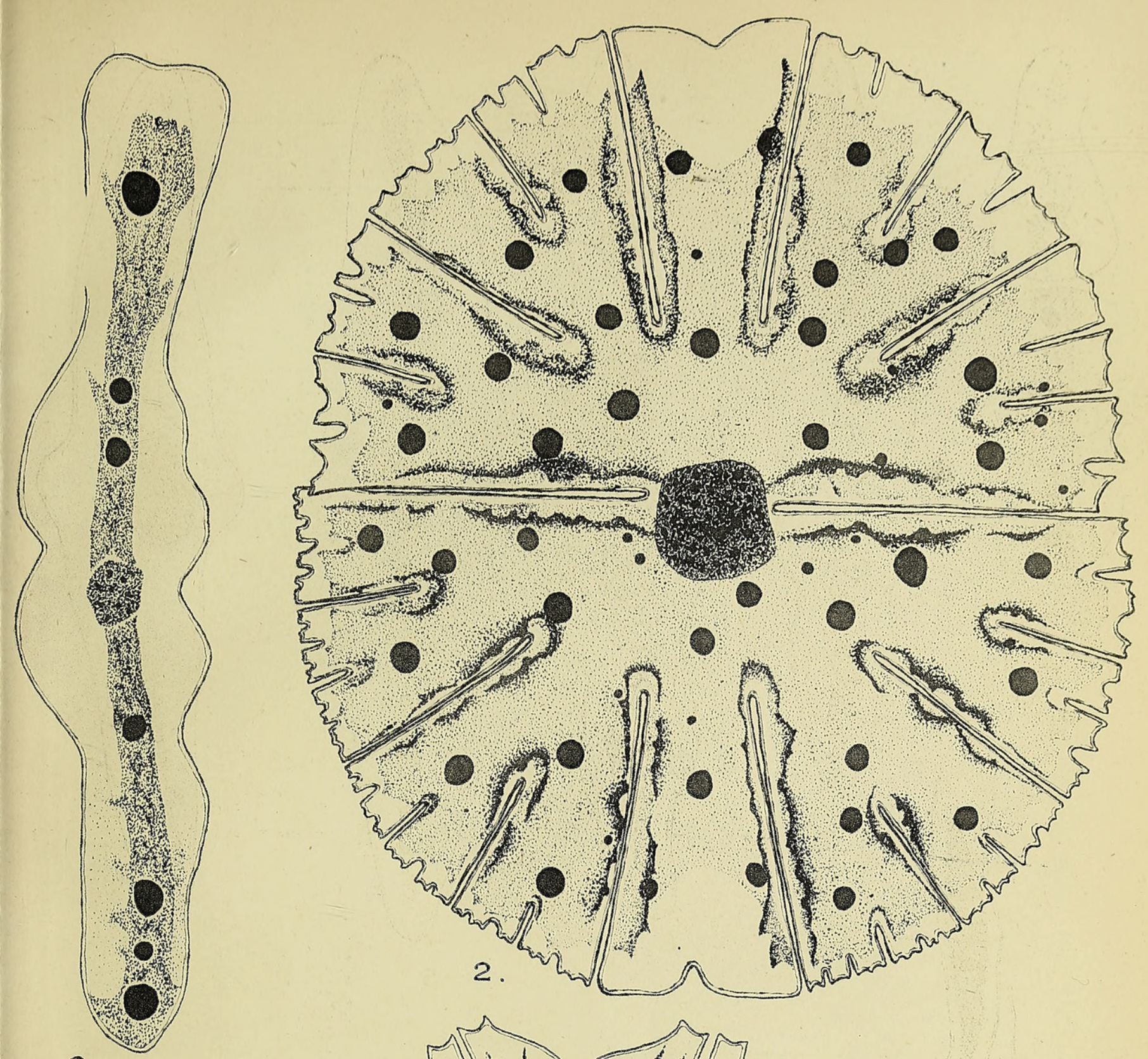

3.

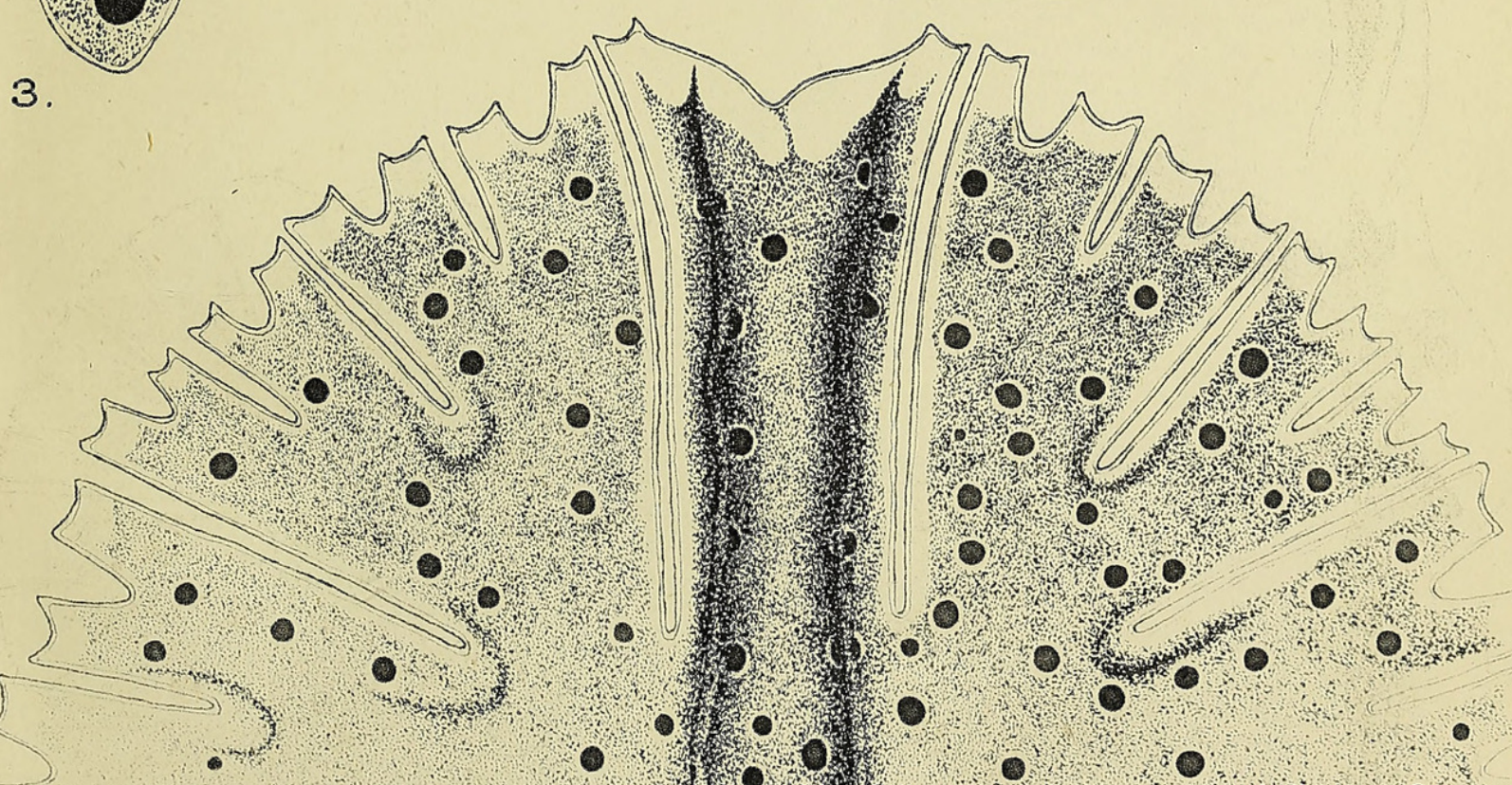

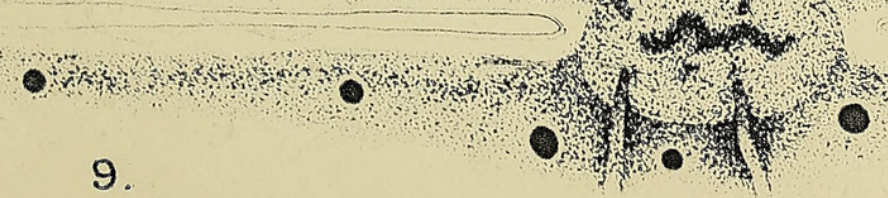


Annals of Botany,

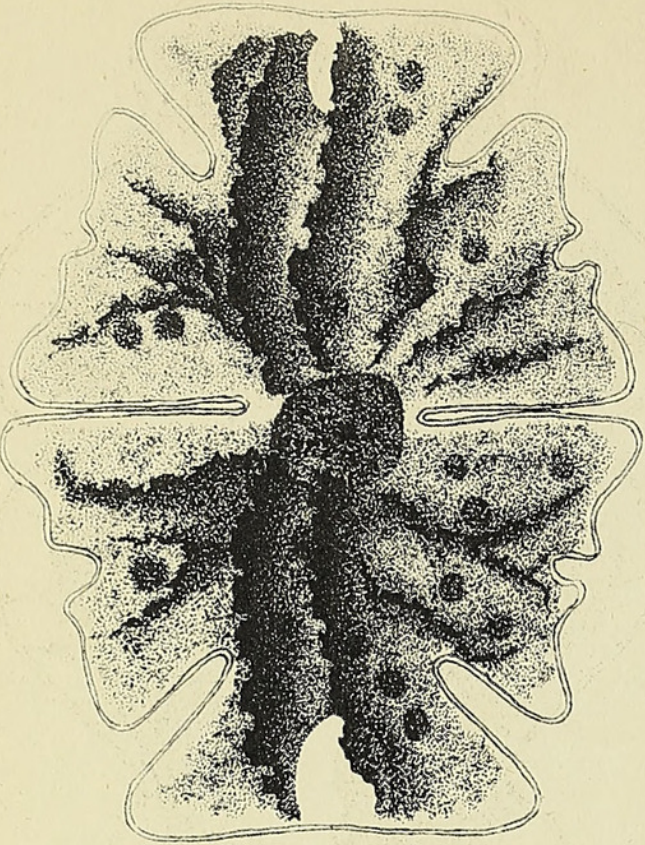

13.

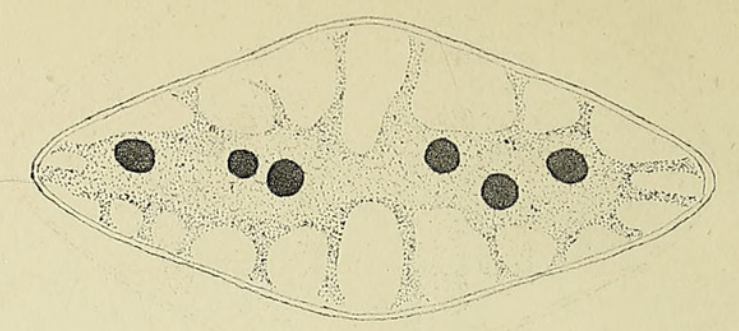

14.

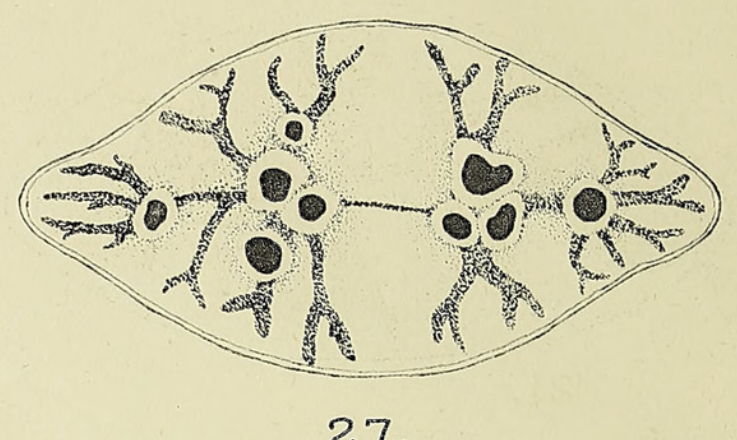

27.

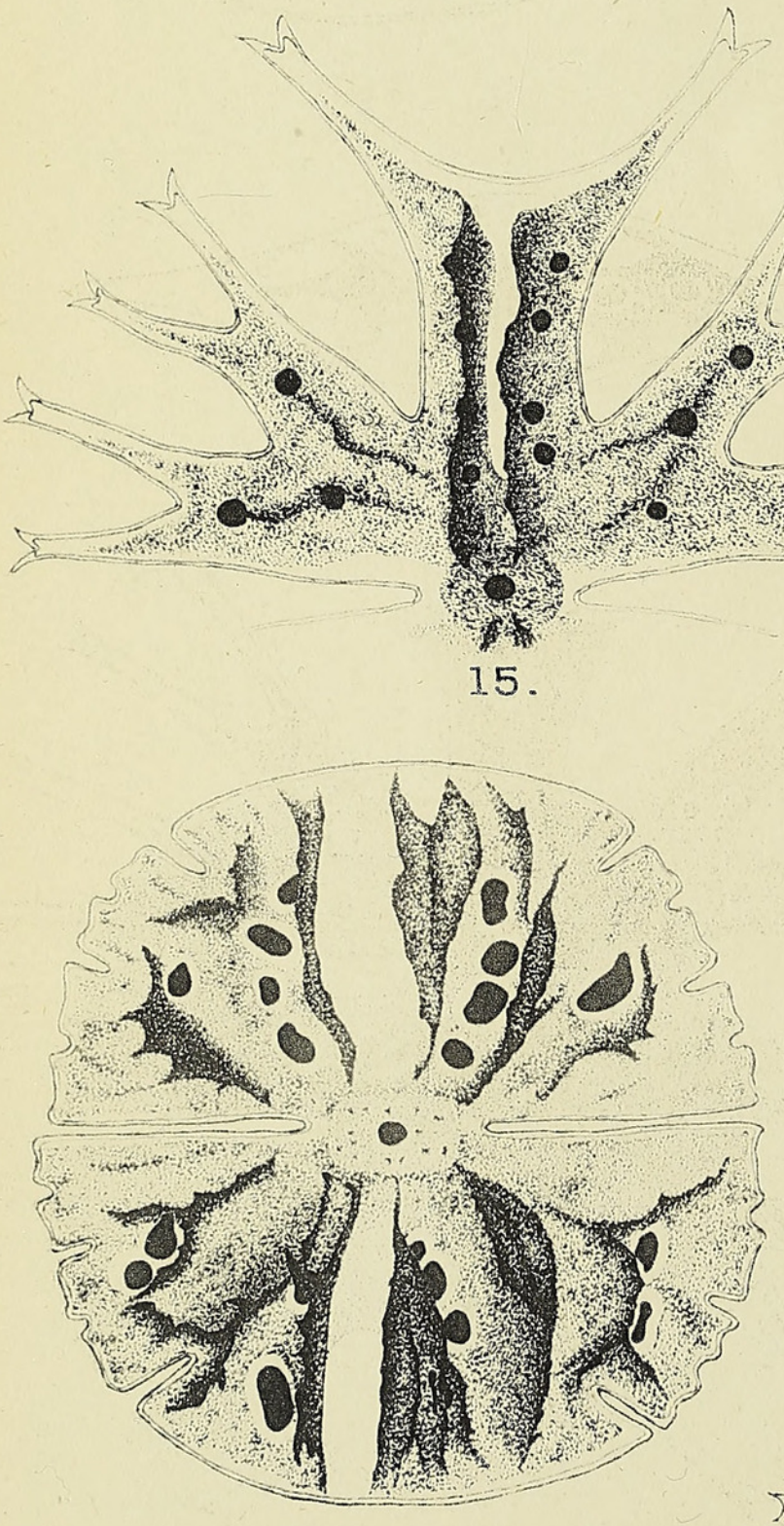

25.
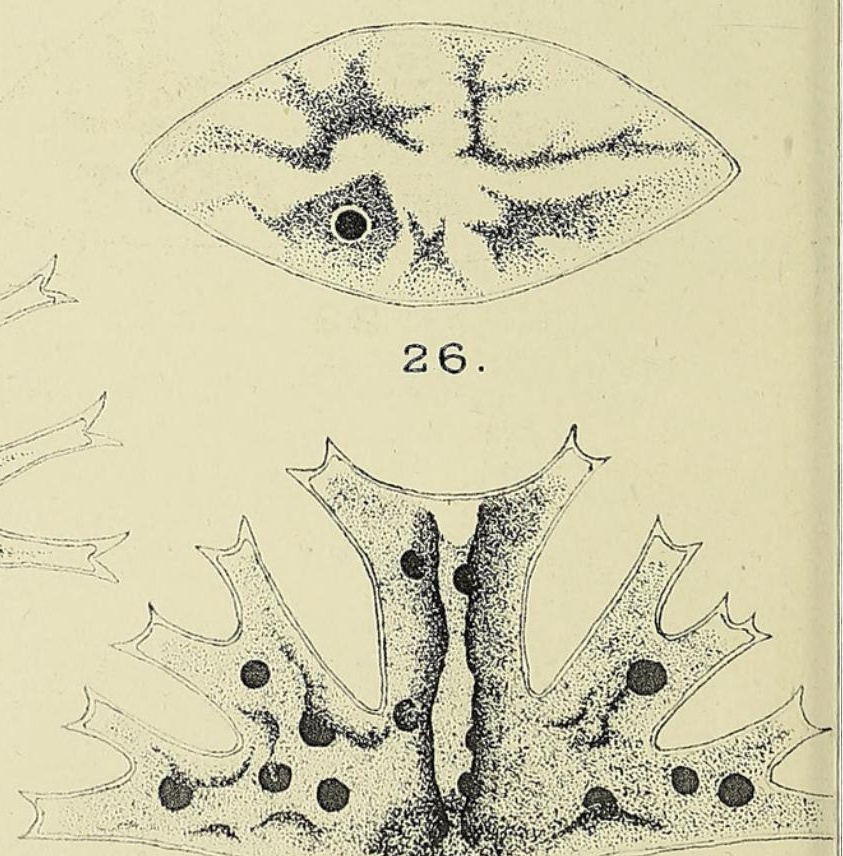

23.

N.CARTER- MICRASTERIAS. 


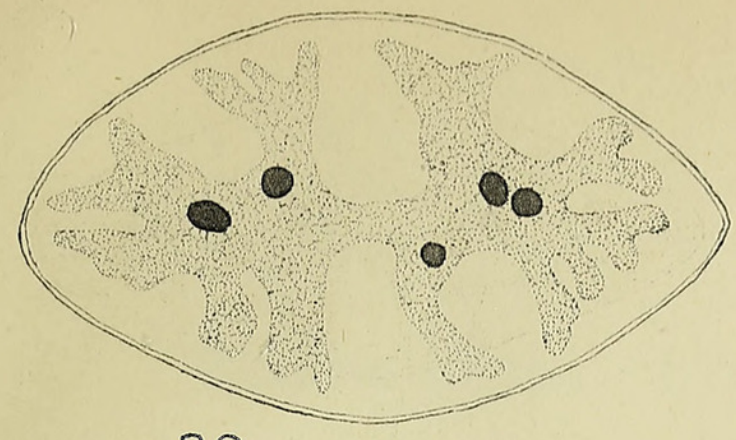

20.

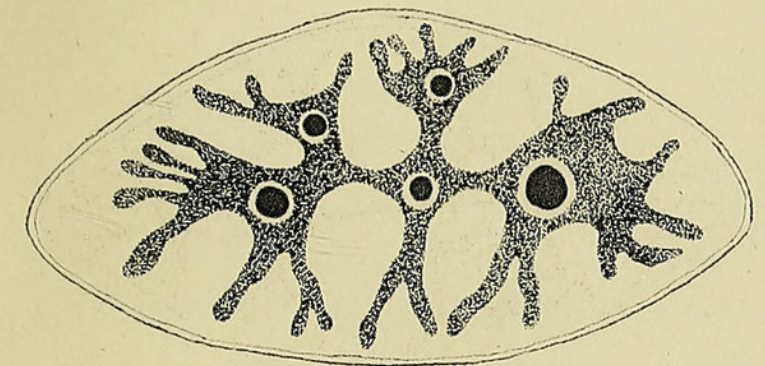

21.
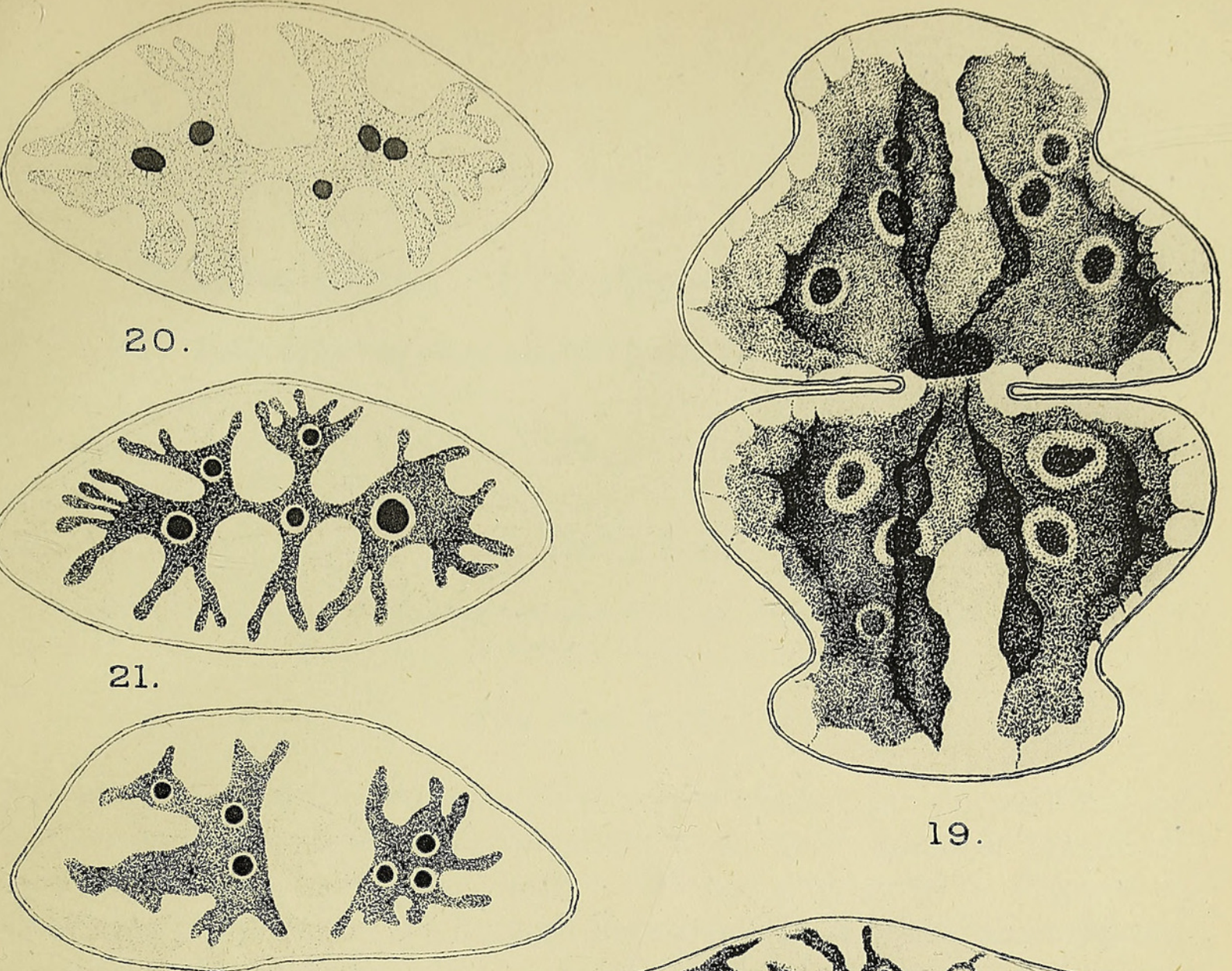

19

22.
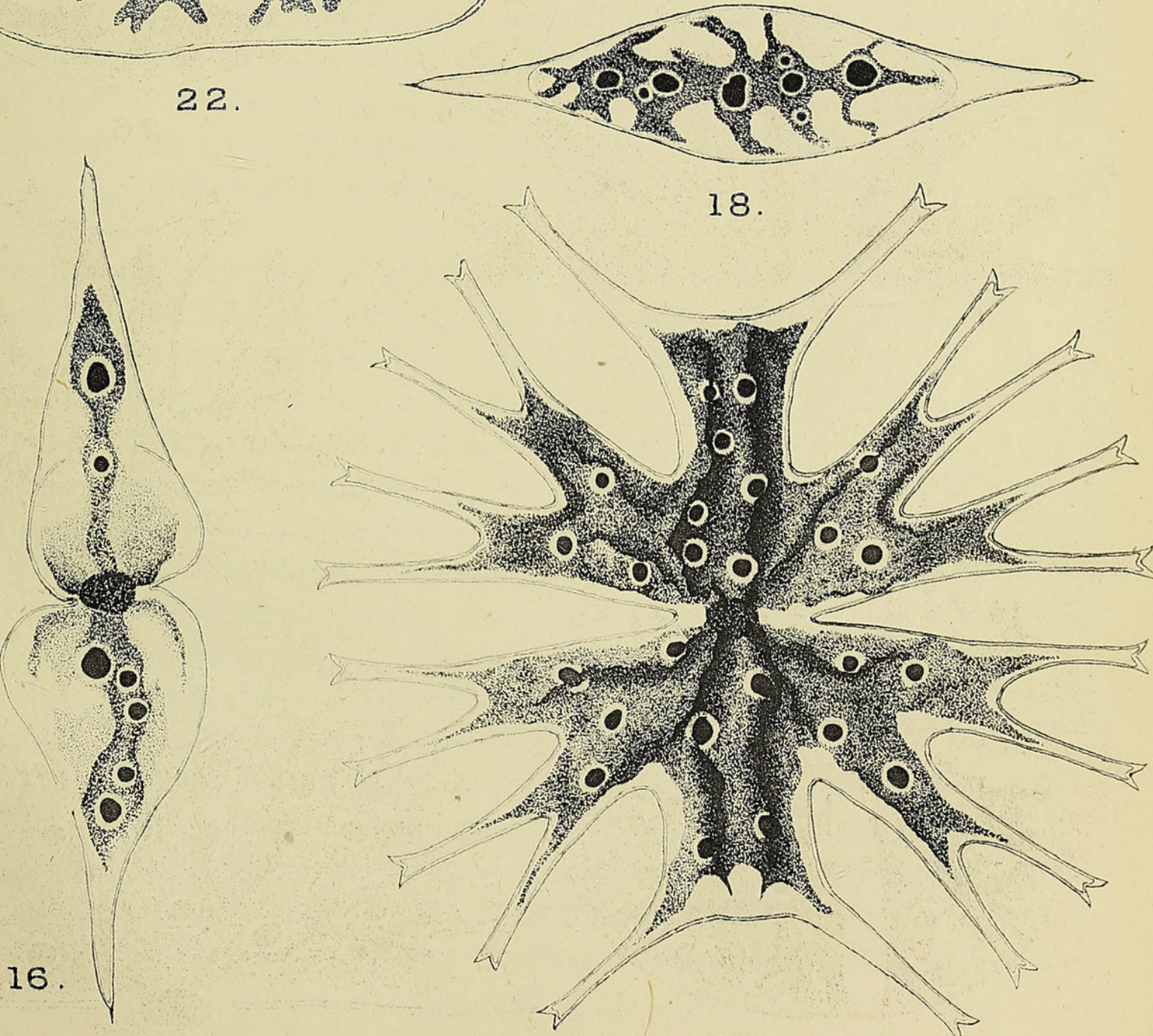


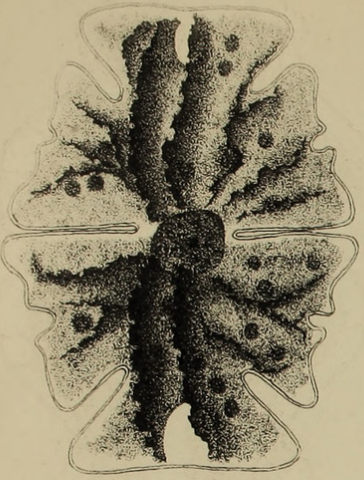

13.

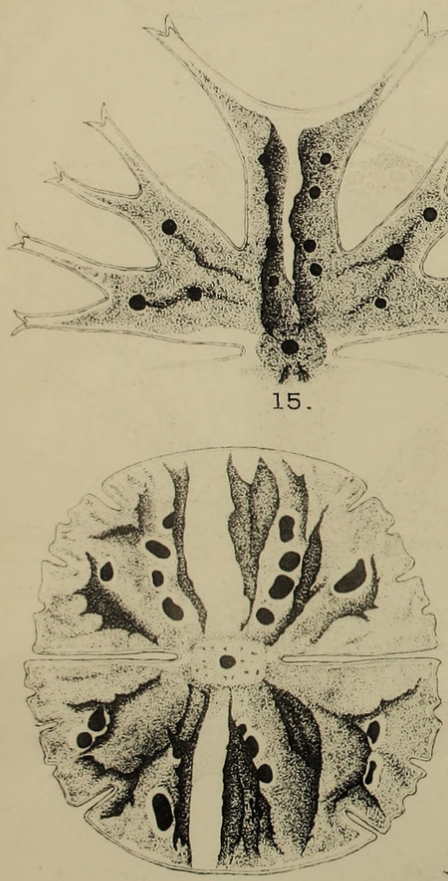

25.

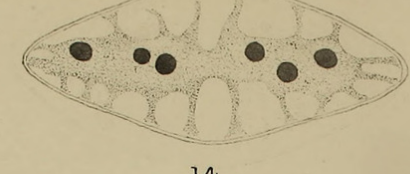

14.

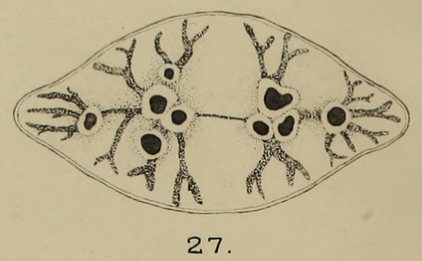

27.
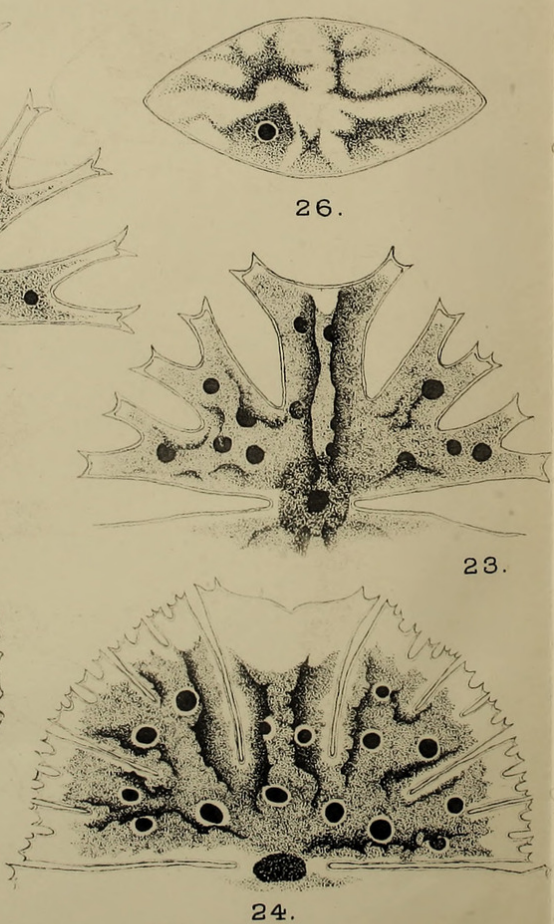

N. CARTER-MICRASTERIAS.
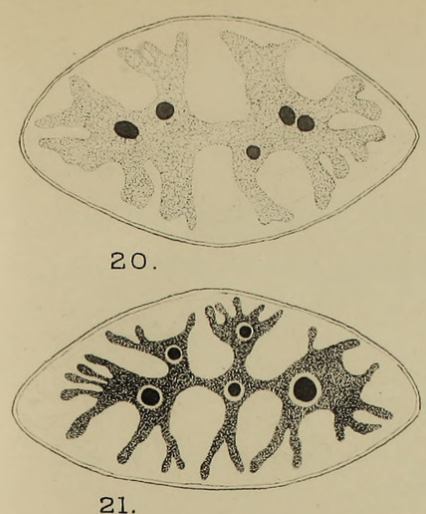

21.

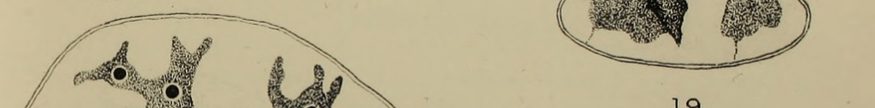

19
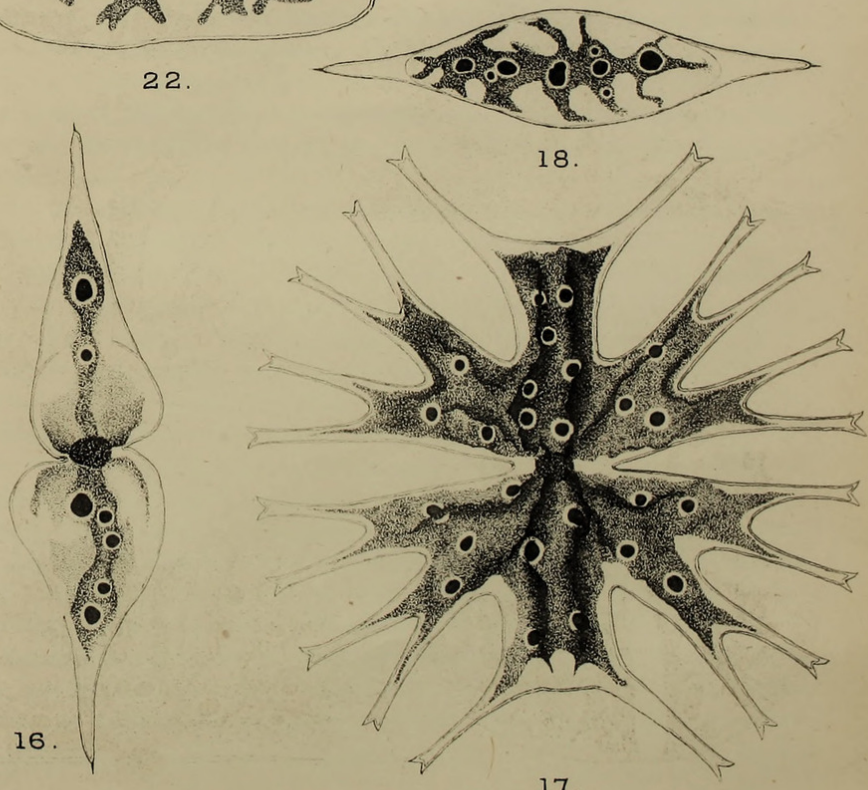

17 


\section{$2 \mathrm{BHL}$ Biodiversity Heritage Library}

Carter, Nellie. 1919. "Studies on the chloroplasts of Desmids. II." Annals of botany 33, 295-304. https://doi.org/10.1093/oxfordjournals.aob.a089723.

View This Item Online: https://www.biodiversitylibrary.org/item/235681

DOI: https://doi.org/10.1093/oxfordjournals.aob.a089723

Permalink: https://www.biodiversitylibrary.org/partpdf/320259

\section{Holding Institution}

Smithsonian Libraries

\section{Sponsored by}

Biodiversity Heritage Library

\section{Copyright \& Reuse}

Copyright Status: Not in copyright. The BHL knows of no copyright restrictions on this item.

This document was created from content at the Biodiversity Heritage Library, the world's largest open access digital library for biodiversity literature and archives. Visit BHL at https://www.biodiversitylibrary.org. 